\title{
Pemberian Ekstrak Kacang Hijau (Phaseolus Radiatus) terhadap Peningkatan Hemoglobin dan Ferritin pada Wistar Putih Anemia
}

\author{
Heni Wijayanti ${ }^{1 凶}$ \\ ${ }^{1,2}$ Sekolah Tinggi IImu Kesehatan Karya Husada Semarang, Indonesia \\ ${ }^{1}$ Surel/Email dan No Telpn heniwijayanti55@gmail.com / 082135333056
}

\begin{tabular}{|c|c|}
\hline Info Artikel & Abstrak \\
\hline $\begin{array}{l}\text { Sejarah Artikel: } \\
\text { Diterima : } 12 \text { Februari } 2020 \\
\text { Disetujui : 06 Juli } 2020 \\
\text { Di Publikasi : } 20 \text { November } \\
2020\end{array}$ & $\begin{array}{l}\text { Kacang hijau, selain mengandung protei, karbohidrat dan lemak juga mengandung zat } \\
\text { besi dan vitamin C yang terbukti dapat memperbaiki anemia pada wanita hamil. Kadar } \\
\text { zat besi yang tinggi berpotensi meningkatkan produksi ROS reaksi fenton. Penelitian ini } \\
\text { untuk membuktikan bahwa pemberian ekstrak kacang hijau dapat meningkatkan kadar } \\
\text { Hb dan kadar Ferritin pada tikus wistar putih.Penelitian ini menggunakan rancangan } \\
\text { Post Test Only Control Group Design.Sebanyak } 25 \text { ekor tikus wistar dibagi menjadi } 5\end{array}$ \\
\hline $\begin{array}{l}\text { Keywords: } \\
\text { Ekstrak Kacang Hijau, Hb dan } \\
\text { Ferritin }\end{array}$ & $\begin{array}{l}\text { kelompok yaitu kelompok normal (Nor-G), kelompok control negative(Neg-G)dan } \\
\text { kelompok perlakuan yang mendapatkan ekstrak kacang hijau } 0,18 \mathrm{~g} \text { (GP-0,18), 0,36g } \\
\text { (GP-0,36) dan } 0,72 \mathrm{~g}(\mathrm{GP}-0,72) \text {. Diet rendah Fe dan ekstrak kacang hijau diberikan } \\
\text { semala } 14 \text { hari. Kadar Hb diukur dengan metode Sahli dan Kadar Ferritin menggunakan }\end{array}$ \\
\hline $\begin{array}{l}\text { DOI: } \\
\text { https://doi.org/10.32763/juke.v } \\
\underline{13 \mathrm{i} 2.191}\end{array}$ & $\begin{array}{l}\text { Kit Immulite Ferritin. Kadar Hd dan ferritin pada kelompok yang mendapatkan ekstrak } \\
\text { kacang hijau } 0,18 \mathrm{~g}(75,56), 0,36 \mathrm{~g}(90,98) \text { dan } 0,72 \mathrm{~g}(95,87) \text { lebih tinggi bermakna, } \\
\text { p }<0,05 \text {. Hasil penelitian ini menunjukkan bahwa pemberian ekstrak kacang hijau } \\
\text { terbukti meningkatkan kadar Hb dan Kadar Ferritin. }\end{array}$ \\
\hline
\end{tabular}

\section{Giving Extract of Green Been (Phaseolus Radiatus) on the Improvement of Hemoglobin and} Ferritin in White Anemia Wistars

\begin{abstract}
Mung bean, not only contain protein, carnohydrates, and fats, but also contains iron and vitamin $\mathrm{C}$ which are to overcome anemia in pregnant women. High iron levels are potential to increase ROS production through fenton reaction. Experiment to prove the administration of mungbean can increase $\mathrm{Hb}$ and ferritin levels in anemic rats. This research uses Post Test Only Control Group Design. A total of 25 anemic rats were divided into 5 groups : normal group (Nor-G), negative control group (Neg-G), were given low Fe diet; and treatment group with low and Fe and mung bean extract at dose of $0,8 \mathrm{~g} / 200 \mathrm{~g} /$ day $(\mathrm{GP}-0,18), 0,36 \mathrm{~g} / 200 \mathrm{~g} /$ day $(\mathrm{GP}-0,36)$, and $0,72 \mathrm{~g} / 200 \mathrm{~g} /$ day $(\mathrm{GP}-0,72)$. Low $\mathrm{Fe}$ diet and mungbean extract were administered for 14 days. $\mathrm{Hb}$ level were measured using Sahli method, and ferritin level using immulite Ferritin Kit.

Compare to Nor-G and Neg-G, levels of ferritin and $\mathrm{Hb}$ on groups with mung bean extract $0,18 \mathrm{~g}(75,56) .0,36 \mathrm{~g}(90,89)$ and $0,72 \mathrm{~g}(95,87)$ were significantly higher $(\mathrm{p}<$ $0,05)$.
\end{abstract}

Alamat korespondensi:

Sekolah Tinggi Ilmu Kesehatan Karya Husada Semarang, Indonesia

ISSN 2597-7520

Email: henwijayanti55@gmail.com

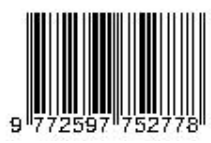

(C)2020 Poltekes Kemenkes 


\section{Pendahuluan}

Anemia defisiensi besi merupakan keadaan yang ditandai dengan penurunan kadar hemoglobin atau jumlah dan mutu sel darah merah yang berkurang. Haemoglobin $(\mathrm{Hb})$ adalah protein dalam darah yang berfungsi sebagai sarana transportasi oksigen seluruh jaringan tubuh. (Almatsier, 2010) Anemia defisiensi besi dapat disebabkan oleh pendarahan atau oleh produksi sel darah merah (erythropoisis) yang rendah oleh sumsum tulang. Produksi sel darah merah yang berhubungan dengan defisiensi besi yang terkandung dalam makanan atau oleh destruksi sel darah merah yang cepat. Diagnosis anemia ditegakkan berdasarkan hasil pemeriksaan kadar hemoglobin dalam darah. (Haider BA, 2013) Kandungan protein, karbohidrat dan lemak pada kacang hijau mendukung proses sintesis hemoglobin. Terdapat beberapa bahan yang diperlukan untuk pembentukan hemoglobin dan sel darah merah (erytrhrocit) antara lain asam folat, besi, cobalt, magnesium, seng, asam amino, vitamin B dan vitamin C. (Dayod M, 2017) Membran eritrosit akan mengalami suatu tekanan osmotic dan menyebabkan hemolisis, sehingga hemoglobin bebas ke dalam medium plasma dan menyebabkan anemia. (Akhtar, 2012)

Penelitian yang pernah dilakukan oeh Nora membuktian bahwa mengkonsumsi jus kacang hijau sebanyak 2 gelas (250cc setiap gelas) per hari selama 7 hari dapat meningkatkan kadar hemoglobin $1,12 \mathrm{gr} / \mathrm{dl}$ dan eritrosit 0,5 juta/ $\mu \mathrm{l}$ pada pasien kanker yang mengalami kemoterapi. (Helty, 2010) Penelitian yang sama yang dilakukan oleh Nora (2011) menyatakan bahwa pemberian kacang hijau dengan dosis 18 $\mathrm{gr} / \mathrm{kgBB} /$ hari dan $36 \mathrm{gr} / \mathrm{kgBB} / \mathrm{hari}$ berpengaruh terhadap peningkatan kadar hemoglobin tikus putih sebesar 16,50 gr/dl dan 14,35 gr/dl (Nora, 2011)

Kandungan protein, karbohidrat dan lemak pada kacang hijau mendukung proses sintesis hemoglobin. Karbohidrat dan lemak membentuk suksinil-KoA yang selanjutnya bersama glisin akan membentuk protoporfirin melalui serangkaian proses porifirinogen. Protoforin yang terbentuk selanjutnya bersama molekul heme dan protein globin membentuk hemoglobin. (Budiwarsono, 2011) Penyerapan zat besi terjadi di usus dua belas jari (duodenum) dan usus halus (jejenum) bagian atas.Zat besi memasuki lambung dari kerongkongan dalam bentuk besi (ferri) kemudian teroksidasi dalam bentuk besi larut (ferro). (Santiago, 2012) Asam lambung akan menurunkan $\mathrm{pH}$ sehingga dapat meningkatkan kelarutan dan penyerapan zat besi. Ketika produksi asam lambung terganggu, penyerapan zat besi juga akan terganggu.Setelah berbentuk ferro, sel mukosa usus pada duodenum dan jejenum akan menyerap zat besi ini. Penyerapan zat besi dibantu oleh protein khusus yaitu transferin (tf). (Guyton, 2010)
Protein tersebut berfungsi mengangkut zat besi dari saluran cerna ke seluruh jaringan tubuh khususnya sumsum tulang belakang, yang akan digunakan untuk membentuk hemoglobin sel darah merah. Asam fitat, tanin, dan antasida dapat memblokir penyerapan zat besi ini. (Astawan, 2010)

Kadar zat besi akan berpengaruh terhadap kadar oksidan berupa Reactive Oxygen Species (ROS). Kadar $\mathrm{Fe} 2+$ yang terdapat dalam transferin dapat digunakan dalam eritropoesis, karena sel "eritroblas" dalam sumsum tulang hanya memiliki "reseptor" untuk feritin. Kadar Fe3+ diubah menjadi Fe2+ dalam usus yang dipengaruhi oleh ferroportin diubah kembali menjadi Fe 2+ dalam darah. Oksidan merupakan senyawa yang dapat mengganggu integritas membrane sel dan memperberat hemolisis. (Ochtavia, 2017)

Peroksidasi membrane eritrosit menyebabkan hemolisis sehingga terjadi penurunan kadar hemoglobin. Dalam penelitian ini, akan dikaji pengaruh ekstrak kacang hijau terhadap kadar $\mathrm{Hb}$ dan kadar ferritin pada tikus Wistar anemia. Hasil penelitian ini diharapkan, ekstrak kacang hijau dengan dosis yang berbeda memberikan pengaruh terhadap cadangan $\mathrm{Fe}$ didalam tubuh dengan pemeriksaan kadar ferritin. (Greer, 2012)

\section{Metode}

Penelitian ini merupakan penelitian eksperimental dengan rancangan Post Test Only Control Group Design. Jumlah sampel dalam penelitian ini adalah 25 ekor tikus wistar yang dibagi menjadi 5 kelompok secara random masing - masing terdiri dari 5 ekor tikus.Kelompok I diberi pakan standar, kelompok II sebagai kelompok kontrol dan hanya di beri aquades selama 14 hari, kelompok III diberi ekstrak kacang hijau dengan dosis $0,18 \mathrm{~g} / 200 \mathrm{~g} /$ hari dalam $3 \mathrm{ml}$ aquades selama 14 hari, kelompok IV diberi ekstrak kacang hijau dengan dosis $0,36 \mathrm{~g} / 200 \mathrm{~g} /$ hari dalam $3 \mathrm{ml}$ aquades selama 14 hari dan kelompok V diberi ekstrak kacang hijau dengan dosis $0,72 \mathrm{~g} / 200 \mathrm{~g} /$ hari dalam $3 \mathrm{ml}$ aquades selama 14 hari.

Ekstraksi Kacang Hijau

Ekstrak kacang hijau diperoleh dengan cara metode maserasi dengan menggunakan air sebagai bahan pelarutnya. Sebelumnya, kacang hijau kering ditumbuk halus, kemudian masing - masing dosis 0,$18 ; 0,36$ dan $0,72 \mathrm{~g} / 200 \mathrm{~g} /$ hari dilarutkan ke dalam $3 \mathrm{ml}$ aquades. Setelah itu, masing - masing larutan disaring menggunakan kertas saring kasar sebagai langkah awal, kemudian disaring menggunakan kertas saring halus. Hasil saringan tersebut merupakan ekstrak dari kacang hijau.Sedangkan perlakuan pathologis (anemia) pada tikus, yaitu dengan pemberian pakanrendah zat besi pada semua tikus wistar putih selama 14 hari secara ad libitum.Sebelum penelitian dilakukan, ethical clearance telah dimintakan dari Komisi Bioetika 
Penelitian Kedokteran/Kesehatan (KBPK) Fakultas kedokteran Universitas Islam Sultan Agung Semarang. Metode Pengukuran Kadar Hemoglobin dan Kadar Ferritin

Kadar Hemoglobin tikus diukur dengan metode $\mathrm{Hb}$ Sahli. $_{\overline{-}} \quad$ Kadar ferritin diukur menggunakan Kit Immulite ferritin dengan cara diambil dari serum $1 \mathrm{cc}$ tiap tikus dan dibaca dengan ELISA reader.

Semua data yang telah didapat ditentukan distribusinya dengan uji normalitas. Normalitas data diuji dengan Shaphiro Wilks karena sampel pada penelitian $<50$. Untuk mengetahui homogenitas data antar kelompok dengan menggunakan uji Levene's test $(\mathrm{p}>0,05)$. Hasil data terdistribusi normal dan homogen memenuhi untuk uji parametrik One Way Anova untuk melihat analisis perbandingan rerata dari 5 kelompok $(\mathrm{K} 1, \mathrm{~K} 2$, K3,K4 dan K5) dilanjutkan dengan uji Post Hoc LSD.

\section{Hasil dan Pembahasan}

Hasil penelitian pada kelompok sampel dengan diberikan perlakuan kacang hijau dengan dosis 0,018 pada kelompok III, dosis 0,036 pada kelompok IV dan dosis 0,072 pada kelompok V maupun pada kelompok yang diet rendah Fe (kontrol) selama 14 hari maka didapatkan hasil yang tertera pada table berikut :

Tabel 1. Perbedaan kadar ferritin tiap kelompok

\begin{tabular}{|c|c|c|c|c|c|c|c|}
\hline \multirow[b]{2}{*}{ Variabel } & \multicolumn{6}{|c|}{ Kelompok } & \multirow[b]{2}{*}{$\mathbf{p}$} \\
\hline & $\mathbf{N}$ & $\begin{array}{c}\text { Nor } \\
\text { mal } \\
\text { (Mea } \\
\text { n } \\
\pm \text { SD) }\end{array}$ & $\begin{array}{c}\text { Kont } \\
\text { rol } \\
\text { (Mea } \\
\text { n } \\
\pm \text { SD) }\end{array}$ & $\begin{array}{c}\text { KH } \\
\mathbf{0 , 1 8} \\
\text { (Mea } \\
\text { n } \\
\pm \text { SD) }\end{array}$ & $\begin{array}{c}\text { KH } \\
\mathbf{0 , 3 6} \\
(\mathrm{Me} \\
\text { an } \\
\pm \mathrm{S} \\
\mathrm{D})\end{array}$ & $\begin{array}{c}\text { KH } \\
\mathbf{0 , 7 2} \\
\text { (Me } \\
\text { an } \\
\pm \text { SD } \\
\text { ) }\end{array}$ & \\
\hline Kadar Sebel & & 12.85 & 6.80 & 6.73 & 6.73 & 6.59 & \\
\hline $\begin{array}{ll}\mathrm{Hb} & \mathrm{um} \\
(\mathrm{gr} / \mathrm{dl}) & \mathrm{Sesu} \\
& \text { dah }\end{array}$ & 5 & 12.75 & 6.72 & 9.09 & $\begin{array}{c}10.1 \\
2\end{array}$ & $\begin{array}{c}11.3 \\
1\end{array}$ & \\
\hline $\begin{array}{l}\text { Kadar } \\
\text { Ferritin } \\
(\mu \mathrm{g} / 1)\end{array}$ & 5 & $\begin{array}{c}110,9 \pm \\
2,4\end{array}$ & $\begin{array}{c}45,09 \\
\pm 3,7\end{array}$ & $\begin{array}{l}75,56 \\
\pm 2,77\end{array}$ & $\begin{array}{r}90,8 \\
9 \pm 1 \\
, 46\end{array}$ & $\begin{array}{c}95,8 \\
7 \pm 2 \\
16\end{array}$ & $\begin{array}{c}0,0 \\
00\end{array}$ \\
\hline
\end{tabular}

Sumber : Data Primer

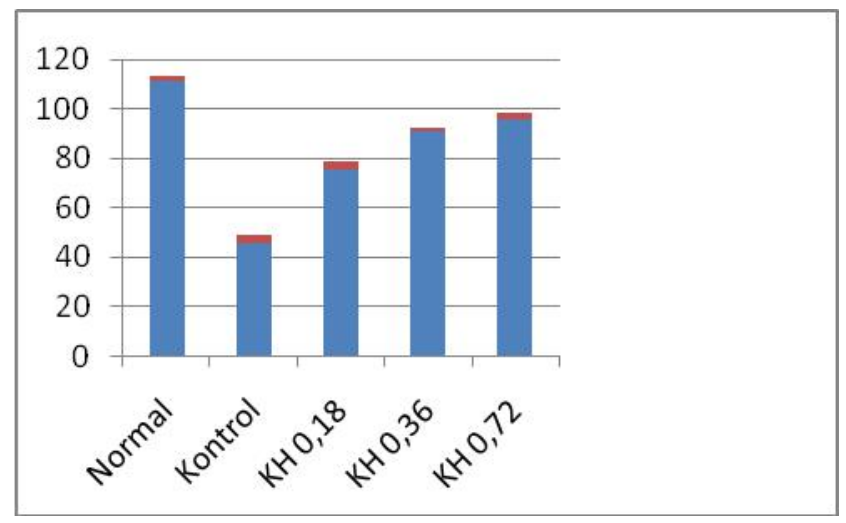

Sumber : Data Primer

\section{Gambar 1. Diagram perbedaan kadar HB dan kadar Ferritin}

Dari tabel 1.terlihat bahwa terjadi kenaikan kadar hemoglobin sebelum dan sesudah perlakuan pemberian ekstrak kacang hijau. Terlihat jelas adanya peningkatan kadar $\mathrm{Hb}$ pada kelompok pemberian kacang hijau dengan dosis $0,18,0,36$ serta 0,72 . Sedangkan pada kelompok normal dan kontrol tidak terjadi perubahan kadar $\mathrm{Hb}$ yang signifikan. Sedangkan tabel 5.1.2 dapat dilihat bahwa urutan kadar feritin dari kelompok tertinggi terdapat pada kelompok normal, kelompok kacang hijau dosis 0,72 , kelompok kacang hijau dosis 0,36 , kelompok kacang hijau dosis 0,18 serta paling rendah kelompok control.

Besi bebas terdapat dalam dua bentukyaitu ferro (Fe 2+) dan ferri $(\mathrm{Fe} 3+)$, konversikedua bentuk tersebut relative mudah. Pada konsentrasi oksigen tinggi, umumnya besi dalam bentuk ferri karena terikat hemoglobin sedangkan pada proses transport transmembran, deposisi dalam bentuk ferritindan sintesis heme, besi dalam bentuk ferro. (Kosasih, 2012) Hal inilah yang menjadi alasan kenapa pada kelompok normal kadar ferritin lebih tinggi karena kelebihan besi disimpan didalam hati dalam bentuk ferritin. (Greer, 2012) Berdasarkan uji normalitas Shapiro Wilks dan uji homogenitas dengan Lavenne Test data kadar hb dan ferritin tikus pada setiap kelompok perlakuan berdistribusi normal dan homogen, sehingga uji yang digunakan One Way Anova. Dari hasil analisa One Way Anova dapat disimpulkan bahwa menunjukkan perbedaan yang signifikan diantara kelompok kadar $\mathrm{hb}$ dan ferritin ditunjukkan nilai $p$ value $=0,00(p<0,05)$. Kemudian gambar dipertegas dengan diagram 1. Uji selanjutnya menggunakan uji Post Hoct LSD Test untuk mengetahui perbedaan setiap kelompok perlakuan. Hasil uji Post Hoct LSD Test seperti pada tabel berikut :

\section{Tabel 2. Analisis Post Hoc perbandingan kadar ferritin antar kelompok}

\begin{tabular}{|c|c|c|c|c|c|c|}
\hline \multirow{2}{*}{$\begin{array}{l}\text { (I) } \\
\text { Perlakuan } \\
\text { pada } \\
\text { kelompok } \\
\text { feritin }\end{array}$} & \multirow{2}{*}{$\begin{array}{l}(\mathrm{J}) \\
\text { Perlakuan } \\
\text { pada } \\
\text { kelompok } \\
\text { feritin }\end{array}$} & \multirow[b]{2}{*}{$\begin{array}{c}\text { Mean } \\
\text { Difference } \\
(\mathrm{I}-\mathrm{J})\end{array}$} & \multirow[b]{2}{*}{$\begin{array}{l}\text { Std. } \\
\text { Error }\end{array}$} & \multirow[b]{2}{*}{ Sig. } & \multicolumn{2}{|c|}{$\begin{array}{l}\text { 95\% Confidence } \\
\text { Interval }\end{array}$} \\
\hline & & & & & $\begin{array}{l}\text { Lower } \\
\text { Bound }\end{array}$ & $\begin{array}{l}\text { Upper } \\
\text { Bound }\end{array}$ \\
\hline \multirow[t]{4}{*}{ Normal } & Kontrol & $65.90600^{*}$ & 1.99499 & .000 & 57.8538 & 73.9582 \\
\hline & КН 0,18 & $35.43400^{*}$ & 1.65305 & .000 & 29.0903 & 41.7777 \\
\hline & КН 0,36 & $20.10000^{*}$ & 1.27138 & .000 & 14.8456 & 25.3544 \\
\hline & КН 0,72 & $15.12200^{*}$ & 1.45936 & .000 & 9.5247 & 20.7193 \\
\hline \multirow[t]{3}{*}{ Kontrol } & КH 0,18 & $-30.47200^{*}$ & 2.08004 & .000 & -38.6422 & -22.3018 \\
\hline & KH 0,36 & $-45.80600^{*}$ & 1.79176 & .000 & -54.1261 & -37.4859 \\
\hline & KH 0,72 & $-50.78400^{*}$ & 1.92969 & .000 & -58.8173 & -42.7507 \\
\hline \multirow{2}{*}{$\begin{array}{l}\text { Kacang } \\
\text { hijau } 0,18\end{array}$} & KH 0,36 & $-15.33400^{*}$ & 1.40107 & .000 & -21.3307 & -9.3373 \\
\hline & KH 0,72 & $-20.31200^{*}$ & 1.57363 & .000 & -26.4419 & -14.1821 \\
\hline
\end{tabular}


Kacang KH 0,72

hijau 0,36

$-4.97800^{*} 1.16625$

$.036 \quad-9.6554$

$-.3006$

\section{Sumber : Data Primer}

Tabel 2.menunjukkan perbandingan antar tiap kelompok pada variabel kadar feritin. Kelompok dengan nilai perbedaan mean tertinggi terdapat dalam perbandingan kelompok normal dengan kelompok kontrol, sedangkan kelompok dengan nilai perbedaan mean terendah terdapat dalam perbandingan kelompok kacang hijau dosis 0,72 dengan kelompok kacang hijau dosis 0,36. Dari hasil analisis post hoc dapat disimpulkan bahwa perbandingan kadar feritin tiap kelompok memiliki pengaruh yang signifikan dengan ditunjukkan nilai $\mathrm{p}$ value $<0,05$.

Perlakuan diet rendah zat besi pada masing - masing kelompok dilakukan selama 14 hari dengan pemberian pakan tanpa zat besi dengan pengawasan ketat. Perlakuan selama 14 hari didasarkan pada penelitian Nora (2011) yang menyatakan perlakuan standar pada hewan coba yaitu selama 14 hari dengan pengawasan ketat. kelompok normal pakan yang diberikan standart, pada kelompok kontrol pakan yang diberikan hanya aquades, sedangkan pada kelompok kacang hijau dosis 0,18 . 0,36 dan 0,72 pakan yang diberikan berupa diet rendah Fe. Dosis tersebut didasari dari jumlah minimal standar dari BB tikus yang berkisar antara 2,5-3 gram. Setelah selesai perlakuan diet rendah Fe selama 14 hari, peneliti mengukur kadar $\mathrm{Hb}$ pada semua sampel. Kelompok normal hasil kadar $\mathrm{Hb}$ masing - masing sampel pada rentang $12,70-13,17 \mathrm{gr} / \mathrm{dl}$, sedangkan pada kelompok dengan perlakuan defisiensi rendah zat besi terjadi penurunan yang signifikan yaitu antara 6,37 $\mathrm{gr} / \mathrm{dl}-6,88 \mathrm{gr} / \mathrm{dl}$. Hal ini sesuai dengan penelitian Pradanti (2012) bahwa anemia defisiensi berhubungan erat dengan status gizi.Sintesis hemoglobin selain dipengaruhi oleh ketersediaan zat besi, juga di pengaruhi oleh kecukupan protein. (Pradanti, 2016) Asam amino yang berupa asam amino glisin dan suksinil koA diperlukan untuk menjadikan protoporfirin dan akhirnya menjadi heme setelah berinteraksi dengan zat besi dengan bantuan enzim ferrocelatase, sedangkan untuk sintesis globin diperlukan asam amino, biotin, asam folat, vitamin B6, dan vitamin B12. Setelah itu, 4 molekul heme berikatan dengan 1 molekul globin membentuk $\mathrm{Hb}$. (Utama, 2013)

Perubahan kadar ferritin yang lebih rendah pada kelompok kontrol dibandingkan dengan kelompok normal menunjukkan bahwa kedua kelompok tersebut memiliki tingkat perbedaan yang signifikan. Pemberian ekstrak kacang hijau dengan dosis $0,18 \mathrm{~g} / 200 \mathrm{~g} / \mathrm{hari}$, $0,36 \mathrm{~g} / 200 \mathrm{~g} / \mathrm{hari}$, serta $0,72 \mathrm{~g} / 200 \mathrm{~g} /$ hari dibandingkan dengan kelompok normal menunjukkan hasil bahwa kelompok normal memiliki kadar ferritin lebih tinggi dari pada kelompok kacang hijau dosis $0,18,0,36$ dan $0,72 \mathrm{~g} / 200 \mathrm{~g} / \mathrm{hari}$. Sedangkan perubahan kadar ferritin pada kelompok kontrol dibandingkan dengan kelompok pemberian kacang hijau dosis $0,18,0,36$ dan $0,72 \mathrm{~g} / 200 \mathrm{~g} / \mathrm{hari}$ menunjukkan hasil bahwa kelompok kontrol memiliki kadar ferritin lebih rendah dari kelompok kacang hijau dosis $0,18,0,36$ dan 0,72 $\mathrm{g} / 200 \mathrm{~g} / \mathrm{hari}$. Hal ini juga diungkapkan dalam penelitian Nora (2011) bahwa perubahan kadar ferritin ini dipengaruhi pemberian dosis ekstrak kacang hijau yang berbeda antar kelompok. (Nora, 2011) Seperti yang kita ketahui bahwa kandungan asam amino biji kacang hijau terdiri dari asam amino esensial yakni isoleusin, leusin, lisin, metionin, fenilalanin, treonin, valin. Selain itu kandungan asam amino non esensial yakni alanin, arginin, asam aspartat, asam glutamate, glisin, triptofan dan tirosin. (Santiago, 2012) Kandungan protein, karbohidrat, dan lemak pada kacang hijau mendukung proses sintesis hemoglobin. Karbohidrat dan lemak membentuk suksinil KoA yang selanjutnya bersama glisin akan membentuk protoporfirin melalui serangkaian proses porifirinogen. Protofirin yang terbentuk selanjutnya bersama molekul heme dan protein globin membentuk hemoglobin. (Astawan, 2010)

Kandungan glisin $0,9 \%$ dari $22 \%$ jumlah asam amino total pada kacang hijau selain mampu membantu sintesis heme dalam hal zat besi juga mampu membantu sintesis heme sebagai bahan pembentuk sintesis heme. (Dayod M, 2017) Ferritin adalah salah satu tipe protein yang menyimpan zat besi. Dalam tubuh zat besi memegang peranan yang sangat penting dalam pembentukan hemoglobin dan sel darah merah, juga akhirnya akan membantu transportasi oksigen keseluruh bagian tubuh. (Guyton, 2010) Pengaruh pemberian kacang hijau terhadap peningkatan kadar hemoglobin tikus putih jantan galur wistar mempunyai hasil bahwa pemberian kacang hijau dengan dosis 18 $\mathrm{gr} / \mathrm{kg} \mathrm{BB} /$ hari dan $36 \mathrm{gr} / \mathrm{kg} \mathrm{BB} /$ hari efektif terhadap peningkatan kadar $\mathrm{Hb} 16,50 \mathrm{gr} / \mathrm{dl}$ dan 16,37 gr/dl.

Kadar MDA pada kelompok normal memiliki nilai paling rendah dibandingkan dengan kelompok pemberian ekstrak kacang hijau dosis $0,18,0,36$ dan $0,72 \mathrm{~g} / 200 \mathrm{~g} / \mathrm{hari}$. Hal ini berbanding terbalik, kelompok kontrol memiliki nilai paling tinggi dibandingkan dengan kelompok pemberian kacang hijau dosis 0,18, 0,36 dan 0,72 g/200g/hari. Hal ini disebabkan karena kacang hijau mengandung senyawa antioksidan alami tumbuhan yang berupa flavonoid.Golongan flavonoid yang memiliki aktivitas antioksidan diantaranya adalah isoflafon. (Harisudin, 2011) Kandungan isoflavon pada kacang hijau sebesar $70,74 \mathrm{mg} / 100 \mathrm{~g}$.Hal ini sama dengan penelitian Patimah (2010) menyatakan bahwa ada pengaruh status anemia terhadap kadar Ferritin sebelum dan sesudah suplementasi besidengan dosis $5,04 \mathrm{mg} / 200 \mathrm{~g}$ berat 
tikus selama 7 hari perlakuan. Dimana suplementasi besi dapat menimbulkan reactive oxygen species (ROS) dan reactive nitrogen species (RNS) serta peroksidasi lipid dan stress oksidatif. Peroksidasi lipid adalah mekanisme trauma sel, sehingga peroksidasi lipid digunakan sebagai penanda stress oksidatif pada sel dan jaringan. (Patimah, 2010)

Kondisi hemoglobin yang meningkat menunjukkan simpanan zat besi yang meningkat.Sementara itu, zat besi $(\mathrm{Fe})$ merupakan salah satu mineral mikro yang juga berperan dalam berbagai system pertahanan antioksidan tubuh, terutama dalam pertahanan enzimatis tubuh. (Dayod M, 2017)

Zat besi $(\mathrm{Fe})$ digunakan sebagai kofaktor dalam enzim katalase.Katalase merupakan merupakan enzim hemotramer yang mengandung feriheme.Aktifitas katalase banyak ditemukan dalam mitokondria. (Greer, 2012)

Katalase berperan sebagai enzim peroksidasi dalam reaksi dekomposisi hydrogen peroksida menjadi oksigen dan air.Enzim tersebut mampu mengoksidasi 1 molekul hydrogen peroksida menjadi oksigen. (Samsudin, 2011)

Sel - sel yang mengandung katalase dalam jumlah sedikit sangat rentan terhadap serangan peroksidasi .Oleh sebab itu, katalase berperan penting dalam mekanisme pertahanan sel darah merah terhadap oksidator hydrogenperoksida. (Yousef, 2014)

Berdasarkan hal tersebut dapat diindikasikan bahwa terdapat hubungan antara Kadar $\mathrm{Hb}$ dan kadar ferritin, ditunjukkan dengan simpanan besi akan meningkat dan meningkatkan pertahanan enzimatis tubuh terhadap radikal bebas oleh enzim katalase, yang selanjutnya akan meningkatkan status oksidatif dan sebaliknya. (Yousef, 2014) Seiring membaiknya status hemoglobin tubuh, diiringi dengan semakin baik pula status oksidatif tubuh yang ditunjukkan dengan penurunan kadar MDA plasma. (Pradanti, 2016) Kandungan flavonoid termasuk apigenin, kaemferol, quercetin dan rutin juga didapatkan dengan menggunakan Thin Layer Chromatography (TLC). (Santoso, 2010) Flavonoid memiliki fungsi sebagai antioksidan primer, chelators dan superoxide anion scavengers, serta memiliki aktivitas antioksidan yang lebih kuat dalam melawan peroxy radicals dibandingkan dengan vitamin $\mathrm{E}$, vitamin $\mathrm{C}$ dan glutathione. Struktur flavonoid yang memiliki gugus hidroksil dan bertindak sebagai hydrogen donator yang dapat menangkap radikal bebas. (Wasnidar, 2012)

Keterbatasan dalam penelitian ini yaitu belum dapat melihat pengaruh pemberian ekstrak kacang hijau terhadap tikus wistar dengan jenis kelamin dan umur yang berbeda. Pemeriksaan kadar $\mathrm{Hb}$ dan kadar ferritin pada penelitian ini ada kemungkinan bias yang diakibatkan karena tidak dilakukan pengukuran nilai kadar $\mathrm{Hb}$ dan feritin sebelum perlakuan.

\section{Penutup}

Terdapat perbedaan yang signifikan pada pengaruh pemberian ekstrak kacang hijau terhadap kadar $\mathrm{Hb}$ dan kadar ferritin pada tikus wistar anemia $(\mathrm{p}<0,05)$, Peningkatan kadar ferritin terjadi pada kelompok pemberian ekstrak kacang hijau dengan dosis 0,18 $\mathrm{g} / \mathrm{kgBB} /$ hari, $0,36 \mathrm{~g} / \mathrm{kgBB} /$ hari, dan $0,72 \mathrm{~g} / \mathrm{kgBB} /$ hari dibandingkan kelompok control.

\section{Daftar Pustaka}

Akhtar. (2012). Severe anemia during late pregnancy. Jakarta : EGC.

Almatsier. (2010). Prinsip Dasar Ilmu Gizi. Jakarta: Gramedia Pustaka.

Astawan. (2010). Penentuan zat besi pada penyakit anemia. Jurnal Unair , 110-115.

Budiwarsono, R. E. (2011). Pendekatan Diagnosis Anemia. Jakarta: Salemba Medika.

Dayod M, A. M. (2017). Nutritional and antioxidant. Jakarta : EGC .

Greer. (2012). Wintrobe's clinical hematology. USA: Lippincott williams.

Guyton, A. (2010). Fisiologi Kedokteran. Jakarta: EGC.

Haider BA, e. a. (2013). Anemia, prenatal iron use and risk of adverse pregnancy outcomes. Jakarta : EGC .

Harisudin. (2011). Peluang Kacng Hijau sebagai diet manula. Seminar Nasional Paan Fungsional, 146-149.

Helty. (2010). Pengaruh kacang hijau terhadap kadar $\mathrm{Hb}$ dan jumlah sel darah merah dalam konteks asuhan keperawatan pasien kanker dengan kemoterapi. Jurnal Lib UI , 114-129.

Iswandari. (2010). Studi kandungan isoflavin pada kacang hijau dan bubur kacang hijau. Jurnal UNDIP , 189-192. 
Kosasih. (2012). Pemeriksaan laboratorium klinik. Bandung: Alumni Bandung.

Murray. (2014). Biokimia harper. Jakarta: EGC.

Nora, M. (2011). Pengaruh pemberian kacang hijau terhadap peningkatan kadar hb tikus putih jantan galuh wistar. Jurnal UGM , 48-52.

Ochtavia, Z. (2017). Kadar Hb dan Jumlah Eritrosit Tikus Putih Setelah Pemberian Formalin. Jurnal Ilmiah Mahasiswa Veteriner, 56-60.

Patimah. (2010). Pola konsumsi ibu hamil dan hiubungannya dengan kejadian anemia defisiensi besi. Jakarta: Badan penelitian sains dan tehnologi.

Pradanti, C. (2016). Hubungan asupan zat besi dan vitamin C kadar hb pada siswi kelas VIII SMPN 3 Semarang. Jurnal Gizi Unimus, vol II hal 89-94.

Rolfes, w. (2012). Understanding nutrition edisi 12. USA: Belmont.

Samsudin. (2011). Biosintesa Dan Cara Kerja Azadirachtin Sebagai Bahan Aktif Insektisida Nabati. Sukabumi: Balai Penelitian Tanaman Rempah dan Aneka Tanaman.

Santiago. (2012). Ferrosus versus ferric oral iron formulations for the treatment of iron deficiency. Scientific World Jurnal .

Santoso, S. (2010). Perubahan Nilai Hematologi, Biokimia Darah, Bobot Organ dan Bobot Badan Tikus Puth pada Umur Berbeda. Jurnal Venteriner, Vol 2, hal 189-194.

Tarwoto. (2010). Buku Saku anemia pada ibu hamil dan konsep penatalaksanaan. Jakarta: Trans info Media.

Utama. (2013). Perbandingan zat besi dengan dan tanpa vitamin $\mathrm{C}$ terhadap kadar HB wanita usia subur. national public Health, vol 4, hal 56-72.

Wasnidar, t. (2012). Buku saku anemia pada ibu hamil dan konsep penatalaksanaan. Jakarta: Trans info media.
Yousef. (2014). Antioxidant activities and Lipid Lowering Effects of Isoflavone in Male Rabbits. Food and Chemical Toxology, vol 4, hal 178-182.

Zhan. (2011). Meta analysis of theeffect of soy protein containing isoflavon on the lipid. USA: Am $\mathrm{j}$ clin. 